\title{
Postsynaptic mechanisms influencing the duration of depolarization discharges in hyperexcitable neuro-glial networks
}

\author{
Vasily Grigorovsky", Berj L Bardakjian \\ From 24th Annual Computational Neuroscience Meeting: CNS*2015 \\ Prague, Czech Republic. 18-23 July 2015
}

Hyperexcitability in the neural networks is one of the hallmark features of the epileptic brain and can manifest itself as recurrent short or long duration discharges [1]. In rodent models of Rett syndrome, it was found that long duration discharges were indicative of more severe outcomes which can be used as biomarkers for seizurelike activity [2]. Hyperexcitable networks show an increased expression of potassium afterhyperpolarization (AHP) channels [3] and persistent sodium (NaP) channels [4]. Additionally, astrocytes have been implicated in moderating neuronal firing patterns, exhibiting impaired extracellular potassium clearance in epileptic models and potentially contributing to the development of depolarization discharges. However the precise mechanism that distinguishes depolarization discharges into short and long duration has yet to be fully ascertained.

In this study, we developed a branched computational model of CA3 region of hippocampus, consisting of a network of an astrocyte and a pyramidal cell with a feedback inhibitory interneuron. As both potassium and calcium ions have been shown to potentially affect neuronal hyperexcitability, the astrocytic model has both mechanisms - the clearance of potassium through potassium channels, and the influence of astrocyte in the synapse.

Preliminary results show that in hyperexcitable systems with fully working potassium AHP channels depolarization discharges cease after less than a second (Fig. $1 \mathrm{~A})$, classifying them as short duration. With partial dendritic AHP channel blockade the duration of discharges increases, transitioning into long duration discharges (Fig. 1B). In the extreme case where all of the

\footnotetext{
* Correspondence: vasily.grigorovsky@utoronto.ca

Institute of Biomaterials and Biomedical Engineering, University of Toronto, Toronto, Ontario, M5S 3G9, Canada
}

Figure 1 Effects of AHP channel blockade on the duration of epileptic discharges. Somatic voltage under A) normal channel expression, B) partial dendritic AHP blockade, and C) full dendritic AHP blockade. 


\section{Acknowledgements}

We would like to thank CIHR and NSERC for providing the opportunity to investigate neuron-glia interactions.

Published: 18 December 2015

\section{References}

1. Lang M, Wither RG, Colic S, Wu C, Monnier PP, Bardakjian BL, Zhang L, Eubanks JH: Rescue of behavioral and EEG deficits in male and female Mecp2-deficient mice by delayed Mecp2 gene reactivation. Human Molecular Genetics 2014, 23(2):303-318.

2. Colic S, Min Lang, Wither RG, Zhang Liang, Eubanks JH, Bardakjian BL: Characterization of HFOs in short and long duration discharges recorded from in-vivo MeCP2-deficient mice. Conf Proc IEEE Eng Med Biol Soc 2014, 4603-4606.

3. Schulz R, Kirschstein T, Brehme H, Porath K, Mikkat U, Köhling R: Network excitability in a model of chronic temporal lobe epilepsy critically depends on SK channel-mediated AHP currents. Neurobiol Dis 2012, 45(1):337-347.

4. Estacion M, Gasser A, Dib-Hajj SD, Waxman SG: A sodium channel mutation linked to epilepsy increases ramp and persistent current of Nav1.3 and induces hyperexcitability in hippocampal neurons. ExpNeurol 2010, 224(2):362-368

doi:10.1186/1471-2202-16-S1-P9

Cite this article as: Grigorovsky and Bardakjian: Postsynaptic mechanisms influencing the duration of depolarization discharges in hyperexcitable neuro-glial networks. BMC Neuroscience 2015 16(Suppl 1):P9.

\section{Submit your next manuscript to BioMed Central} and take full advantage of:

- Convenient online submission

- Thorough peer review

- No space constraints or color figure charges

- Immediate publication on acceptance

- Inclusion in PubMed, CAS, Scopus and Google Scholar

- Research which is freely available for redistribution

Submit your manuscript at www.biomedcentral.com/submit
Ciomed Central 